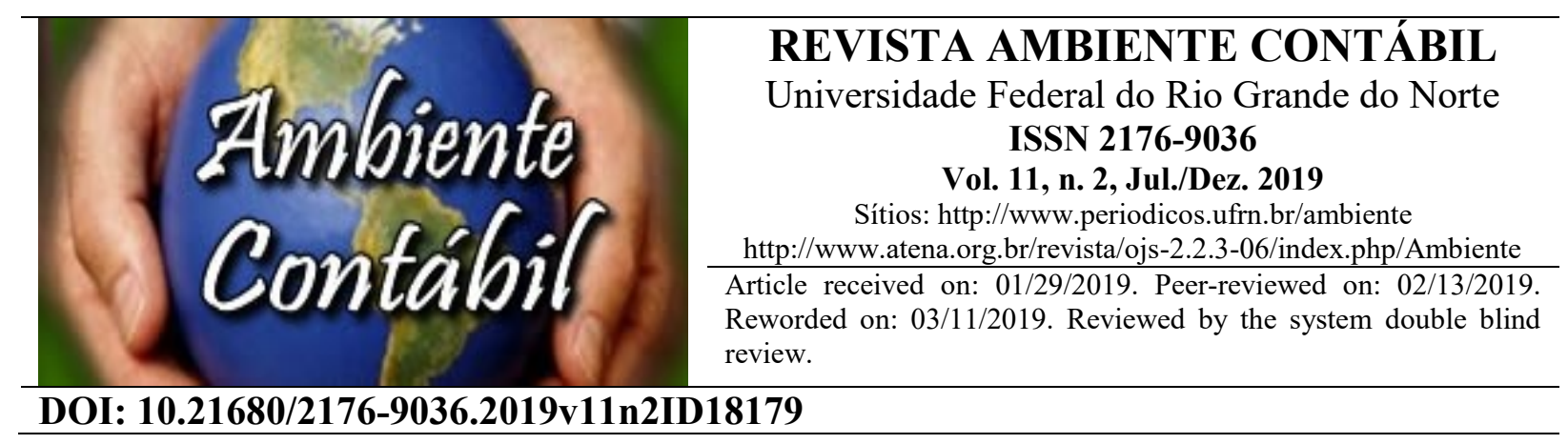

Perception of the students of the course of accounting sciences and the specialization in skills and auditing about teaching and the labor market in auditing

Percepción de los discentes del curso de ciencias contables y de la especialización en pericia y auditoría sobre la enseñanza y el mercado de trabajo en auditoría

Percepção dos discentes do curso de ciências contábeis e da especialização em perícia e auditoria cerca do ensino e do mercado de trabalho em auditoria

\title{
Márcia Bianchi
}

Master's degree in Development Economics - Federal University of Rio Grande do Sul (UFRGS). Professor of PPGCONT at UFRGS. Address: Rua João Pessoa, 52, sala 11, Accounting and Actuarial Department, Centro, Porto Alegre, RS - Brasil, CEP 90040-000. Identifiers (ID):

ORCID: http://orcid.org/0000-0002-7716-2767

Lattes: http://lattes.cnpq.br/0461322489692161

E-mail: marcia.bianchi@ufrgs.br

\section{Jorge Daniel Werlang}

Expertise and Audit Specialist - Federal University of Rio Grande do Sul (UFRGS). Address: Rua João Pessoa, 52, sala 11, Accounting and Actuarial Department, Centro, Porto Alegre, RS - Brasil, CEP 90040-000.

Identifiers (ID):

ORCID: https://orcid.org/0000-0002-6167-9294

E-mail: jdwerlang@yahoo.com.br

\section{Lauren Dal Bem Venturini}

Master in Controlling and Accounting of Postgraduate Program at Federal University of Rio Grande do Sul (UFRGS). Address: Rua João Pessoa, 52, sala 11, Accounting and Actuarial Department, Centro, Porto Alegre, RS - Brasil, CEP 90040-000.

Identifiers (ID):

ORCID: http://orcid.org/0000-0003-4185-9842

Lattes: http://lattes.cnpq.br/7879317327685850

E-mail: laurenventurini@hotmail.com 


\section{Vanessa Noguez Machado}

Master in the Controlling and Accounting Postgraduate Program at Federal University of Rio Grande do Sul. Address: Rua João Pessoa, 52, sala 11, Accounting and Actuarial Department, Centro, Porto Alegre, RS - Brasil, CEP 90040-000.

Identifiers (ID):

ORCID: https://orcid.org/0000-0002-5006-5203

Lattes: http://lattes.cnpq.br/8733928707738415

E-mail: vanessa_nm93@hotmail.com

\section{Abstract}

Purpose: This study aims to identify Universidade Federal do Rio Grande do Sul (UFRGS) Accounting Sciences (Group 1) and Specialization in Skills and Auditing (Group 2) students' perception regarding teaching and content of auditing for preparation and insertion into the job market.

Methodology: Quantitative, descriptive and survey research through a questionary application (open and closed questions) to students of the two courses, seeking to identify the groups' characteristics and their understanding concerning teaching and learning methods from the audit discipline for the labor market.

Results: It was verified that the majority of the two groups are in the labor market and that auditors intend to remain in this work area. As for the pedagogical practices, in the two groups stood out: "Exhibition Classroom"; "Classroom Discussions"; "Resolutions of Exercises"; and "Case Studies". Group 1 pointed out the aspects that need to be deepened: "Brazilian Accounting Standards", "Audit Planning", and "Practices in fraud detection", and for Group 2 these aspects are: "Legislation Applicable to Accounting Audit", "Audit Planning" and "Audit Execution". In relation to the sufficiency perception of discipline content to perform the function, 37\% of Group 1 and $46.7 \%$ of Group 2 believe that it is insufficient and they are concerned with the impact on the activities' development in the labor market. Still, as a motivation to study auditing, students claim that such knowledge is indispensable for the profession good performance in order to master accounting practice content in regard to legislation and auditing standards.

Contributions of the Study: The results help courses' responsible to propose improvements for course development, for the course itself and, consequently, for accounting professional.

Keywords: Audit. Teaching. Labor market.

\section{Resumen}

Objetivo: El objetivo del estudio es identificar la percepción de los discentes del curso de Ciencias Contables (Group 1) y de la Especialización en Experiencia y Auditoría (Group 2) de la Universidade Federal do Rio Grande do Sul (UFRGS) acerca de la enseñanza y del contenido de auditoría para la preparación e inserción en el mercado de trabajo.

Metodología: Investigación cuantitativa, descriptiva y de levantamiento por medio de la aplicación de cuestionario (preguntas abiertas y cerradas) a los alumnos de los dos cursos, 
buscando identificar las características de los Grupos y su comprensión en cuanto a los métodos de enseñanza y aprendizaje de la disciplina de auditoría para el mercado de trabajo.

Resultados: Se verificó que la mayoría de los dos Grupos se encuentra en el mercado de trabajo, y que los actuantes en auditoría pretenden permanecer en el área. En cuanto a las prácticas pedagógicas, en los dos Grupos se destacó: "Aula Expositiva"; "Discusiones en Sala de clase"; "Resoluciones de Ejercicios"; y "Estudios de caso". En el Group 2, los aspectos señalados que carecen de profundización en el Group 1 son: "Normas Brasileñas de Contabilidad", "Planificación de la Auditoría", y "Prácticas en la detección de fraudes", y en el Group 2 fueron: "Legislación Aplicable a la Auditoría Contable ", "Planificación de la Auditoría" y "Ejecución de los trabajos de auditoría". En cuanto a la percepción sobre la suficiencia del contenido de la disciplina para el desempeño de la función, el 37\% del Group 1 y el $46,7 \%$ del Group 2 creen que es insuficiente y se preocupan por el impacto de ello en el desarrollo de las actividades en el mercado de trabajo. Además, como motivación para estudiar auditoría, los discursos alegan que tal conocimiento es indispensable para el buen desempeño de la profesión, a fin de tener dominio del contenido sobre la práctica contable en relación a la legislación y normas de auditoría.

Contribuciones del Estudio: Los resultados ayudan a los responsables de los cursos a proponer mejoras en el desarrollo de la disciplina, en el curso y, consecuentemente, del profesional de contabilidad.

Palabras clave: Auditoría. Educación. Mercado de trabajo.

\section{Resumo}

Objetivo: O objetivo do estudo é identificar a percepção dos discentes do curso de Ciências Contábeis (Group 1) e da Especialização em Perícia e Audit (Group 2) da Universidade Federal do Rio Grande do Sul (UFRGS) acerca do ensino e do conteúdo de Auditoria para a preparação e inserção no mercado de trabalho.

Metodologia: Pesquisa quantitativa, descritiva e de levantamento por meio da aplicação de questionário (questões abertas e fechadas) aos alunos dos dois cursos, buscando identificar as características dos grupos e sua compreensão quanto aos métodos de ensino e aprendizagem da disciplina de Auditoria para o mercado de trabalho.

Resultados: Verificou-se que a maioria dos dois grupos se encontra no mercado de trabalho, e que os atuantes em Auditoria pretendem permanecer na área. Quanto às práticas pedagógicas, nos dois grupos destacou-se: "Aula Expositiva"; "Discussões em Sala de Aula"; "Resoluções de Exercícios"; e "Estudos de Caso". Já, os aspectos apontados que carecem de aprofundamento no Group 1 são: "Normas Brasileiras de Contabilidade", "Planejamento da Auditoria", e "Práticas na detecção de fraudes", e no Group 2 foram: "Legislação Aplicável à Auditoria Contábil", "Planejamento da Auditoria" e "Execução dos trabalhos de auditoria". Em relação à percepção sobre a suficiência do conteúdo da disciplina para desempenho da função, $37 \%$ do Group 1 e 46,7\% do Group 2 acreditam que é insuficiente e se preocupam com o impacto disso no desenvolvimento das atividades no mercado de trabalho. Ainda, como motivação para estudar auditoria, os discentes alegam que tal conhecimento é indispensável para o bom desempenho da profissão, a fim de ter domínio do conteúdo sobre a prática contábil em relação à legislação e normas de auditoria. 
Contribuições do Estudo: Os resultados auxiliam os responsáveis dos cursos a propor melhorias no desenvolvimento da disciplina, no curso e, consequentemente, do profissional contábil.

Palavras-chave: Auditoria. Ensino. Mercado de Trabalho.

\section{Introduction}

The auditing has been suffering changes since the beginning of XXI century, resulting from the growing development of world capitalist society and from the accounting, financial and audit frauds episodes of Enron, Worldcom and Parmalat enterprises (Armitage, 2008; Castañeda, Oak, \& Lisbon, 2007). Frauds as those culminated in the Law Sarbanes-Oxley approval and in the Public Company Accounting Oversight Board (PCAOB) creation, generating new responsibilities for audit professionals (Armitage, 2008). For Castañeda et al. (2007), the constant changes in auditing showed up the eminent necessity of a reflection, as for the independent auditor role, and demonstrated the importance assigned to accounting standards and auditing convergence process to global levels, and being the decisive factor in the capital market reliability increase.

Bearing in mind that the alterations in auditing work development have affected its practice and its teaching, it is necessary to reassess the education accounting process continuously, in order to meet the needs of a changeable society and to prepare, in an appropriate form, the future professional for a career of success (Armitage, 2008). In accordance with Armitage and Poyzer (2010), teachers on audit area face challenge to guarantee the students' best preparation for the business world since they should provide all the necessary skills to ensure that the pupils will be able to be inserted in the labor market and to reach the professional success. The preparation of Accounting Sciences curricula and courses contents projection, contemplating the market and professional evolutions needs (Hoff, Alberton, \& Camargo, 2017), addresses this requisite.

In this context, this research has the following problem: which is the perception of Federal University of Rio Grande do Sul (UFRGS) Accounting and Specialist in Inspection and Audit courses students regarding audit teaching and their preparation for the labor market? To answer that question this study aims to analyze the perception of UFRGS Accounting course's students and of the UFRGS Center of Studies and Researches in Accounting (NECON) course of Specialist in Inspection and Audit pupils regarding Audit teaching content and the preparation for their insertion in the labor market.

This study is relevant due to the audit teaching process evaluation importance, through the students' perception of the subject, since it draws on a comparison between apprenticeship and market's expectations, providing an education review in order to optimize it (Armitage, 2008; Chaffey, Van Peursem, \& Low, 2011). In line with Silva et al. (2016), studies in Brazilian universities, wrapping motivation of the future and possible auditors are valuable since they demonstrate the motives that arouse the interest to choose this activity.

Differently of other Brazilian studies - which approach the audit teaching based on related disciplines to the Accounting courses' thematic (Madeira, 2001; Ricardino, 2002), comparing graduation pupils' perspectives to auditors yet in the labor market (Hoff et al., 2017; Machado, Machado, \& Guerra, 2014; Silva, 2008) or they show the students' motivation in terms of the insertion into the audit labor market (Silva, Martins, \& Rocha, 2016)-, this research promotes the empirical enrichment with respect to the audit teaching and its contributions based on the pupils' perception, either in the Accounting Graduation or in the 
Inspection and the Auditing Postgraduate course, so that it highlights the subjects related to the auditing that are considered by students more relevant and if the audit teaching is considered sufficient to heal the professional practice expectations.

Therefore, this study's results contribute to the Accounting courses responsible, as well as to the specializations related to Auditing, have a better understanding of the necessary attributes for the Audit apprenticeship, aiming to the accounting professional's needs facing labor market. Still, the research helps to propose actions that enhance the audit teaching and, consequently, the accounting profession, impacting the accountant qualification as a whole.

Consequently, this study is organized into five sections, including this introduction. Section 2 approaches the theoretical revision on auditing and labor market, audit teaching and related studies. The third section brings the methodological procedures and the population studied. Section 4 presents the results and relevant discussions. Finally, the fifth section describes the conclusions of the article.

\section{Theoretical Frame}

This section presents the audit's foundations and its context in the labor market and in the teaching, as well as in the studies related to the topic.

\subsection{Audit and Labor Market}

Recently, the audit's field has increasingly expanded, having in mind the quantity of scandals presented by the media involving audit firms, and/or corporations audited by great auditing names in the world, such as: Enron, Worldcom, and Parmalat, which led to the creation of a new law in the United States (USA), the Law Sarbanes-Oxley, or, more commonly known as SOX, and to the creation of the Public Company Accounting Oversight Board (PCAOB) (Armitage, 2008; Castañeda et al., 2007). In Brazil, it culminated with the publication of Law $\mathrm{n}^{\circ}$. 11.638/2007, adopting a new accounting standard, joining the International Accounting Standards, the International Financial Reporting Standards (IFRS) (Hoff et al., 2017).

The auditing realization scope is combined in two groups: internal or external, each one with its own objectives and characteristics. As per Franc and Horn (2000), the auditing can be defined as the technique that examines, investigates, and analyses in a methodical way the transactions, operations, processes, routines, and the economic-financial statements of a certain institution, public or private, aiming to obtain information and confirmations.

The internal auditing is developed by an employee from the organization and is not subordinated to any collaborator whose work he will examine, and he does not develop any actions that he would need to investigate in the future (Almeida, 2012). The objective of this auditing is to evaluate if the accounting and internal control system, settled by the administration, it is being implemented correctly or if it requires improvement (Oliveira, \& Diniz, 2001). The external audit, also known as independent audit, is the specialty that organizations contract audit firms to analyze their financial statements, in other words, the auditor does not have an employment bond with the audited company, but independence, in order to deliver an opinion pertaining to the financial demonstrations examined, regarding the adaptation of the Accounting Principles (Camargo, Camargo, Dutra, \& Alberton, 2013). This audit development requires a good planning, evaluation of the internal control related to the accounting part, asset's accounts, liabilities, receipts, and expenses analytical review, among 
others, and observation of the applicable legislation (Castro, Vasconcelos, \& Dantas, 2017), in other words, lacks technical knowledge and professional training.

To pursue the auditor's activity and to sign the reports, Accounting graduation is essential, since the accountancy technician is not enabled to exercise this prerogative. Another demand is to be duly registered in the Regional Accountancy Council (CRC). Besides, to maintain the registration in regulatory bodies, the auditor must participate in activities in the Continued Education Program, carried out by the CRCs, aiming to keep up to date with rules and regulations. And, in order to audit open companies and member institutions of the property market, the professional needs to sign up with the Securities and Exchange Commission (CVM), which regularizes these organizations (Barreto, \& Graeff, 2011).

In turn, the audit labor market is looking for competent and prepared professionals, and experts about the applicable legislation to the auditor job, since the more qualified is the auditor, the better will be the quality of his work (Alberton, \& Beuren, 2013). In the great enterprises of auditing there is space for beginners, graduation and recently graduated students, joining through selection and later they receive training and capabilities so they will be able to develop their skills, besides providing academy interaction with the labor market, during the course or right after its finalization (Madeira, 2001).

In the independent auditor qualification, the behavior aspect needs to be considered with emphasis, and not only focus on the technical aspects and the legislation attendance (Camargo et al., 2013). The study of Silva et al. (2016) disclosed that the auditor's career most attractive factors for the students are: compensation; to acquire knowledge and experience; the profession relevance. The elements that put the students off are the quantity of career prerequisite; lack of opportunity in the firms of the sector; elevated workload. Still, the students face impediments to the entry in this professional field, since the auditing companies seek for ready, skillful and qualified professionals.

\subsection{Audit Teaching}

The modifications that have been occurring over the years in auditing, due to the corporate scandals, the new accounting and auditing standards and the growing demand from the labor market, have created a challenge for the teachers and for the teaching institutions as for the academical curricula development that would contribute in an effective way in the Accounting students intellectual construction, in order to prepare them to be success audit professionals (Armitage, \& Poyzer, 2010). In the words of Madeira (2001), there is a growing effort in several countries for the enlargement of the relation between the teaching and the market, to exist a bigger integration between research, extension, and teaching.

Madeira (2001) emphasizes the need for improvements in the audit apprenticeship process in the course, as historically the pupils have shown they are insufficiently prepared for the market. Such sufficiency, when the student is inserted into the market, would reduce at acceptable levels the inadequate opinion issuance risk related to the financial reports examined, as well as the understanding of the business relations complexities and the choice and the use of appropriated methodologies in the performance of his tasks (Ricardino, 2002).

In turn, according to Humphrey (2008), the joint work on the part of the audit researches and professionals become essential, as a way to ally the knowledge related to the theoretical framework to the profession practical living existence for strides in the teaching area and the practical knowledge development. Hoff et al. (2017) affirm that the audit teaching methodology thought like more adequate by professional auditors has expositive classrooms, case studies, exercises resolution, and seminars. In the same study, teachers 
defend the union of these methodologies as an approach adopted for their class development. However, the authors realized that "a great piece of those uses only expositive class as an approach for the teaching process and apprenticeship in auditing" (Hoff et al., 2017, p. 60).

Hence, Silva and Bruni (2017) mentioned the teacher's role in the future accounting professional education. For these authors, teachers must consider, starting in the planning of their class, so that pedagogic active practices, such as seminars, engage the students with debates and inquiries, and do not only unduly transfer the presentation of a subject/topic responsibility to students.

The research's approach into the audit practice and into the influence exerted by regulatory bodies becomes more effective for the students, having in mind the existing gap in the apprenticeship methodology exclusively theoretical. The existence of a distance between the audit professional practice and the scientific field makes the knowledge's legitimacy become little explored (Humphrey, 2008). In this context, the university is seen as essential for the students' qualification, in order for them to be professionals that are able to provide the demands of a labor market in a constantly changing, acting as agents carrying changes in continuous evolution (Hoff et al., 2017; Silva, 2008).

For this purpose, the academic curricula and the program contents projection that meets the needs of the market is the Accounting course main challenge (Hoff et al., 2017). For such, Madeira (2001) sustains that the educational institutions will have to prepare in an appropriate way the accountants for their inclusion into the job market, offering accurate and adjusted curricula in compliance to the employment market demands and its new context. Armitage and Poyzer (2010) believe that the biggest responsibility when updating the curricula is of the teachers, who must be attentive to the profession changes in order to incorporate these changes in the class program.

\subsection{Related Studies}

In order to elucidate studies related to the research state-of-the-art, Table 1 is presented. 
Table 1

Related Studies

\begin{tabular}{c|l|l}
\hline Autor(es) & \multicolumn{1}{|c}{ Objetivo } & \multicolumn{1}{c}{ Resultados } \\
\hline \multirow{3}{*}{ Madeira (2001) } & $\begin{array}{l}\text { To evaluate the audit's apprenticeship } \\
\text { comparing the academic curricula and the } \\
\text { perception of the auditors attending the } \\
\text { 16th Intergovernmental Work Group } \\
\text { Meeting of Accounting and Financial } \\
\text { Reports International Standards Specialists } \\
\text { requisite for the audit profession is fulfilled } \\
\text { (ISAR), from the academic curricula, showing } \\
\text { Accounting professional's insufficient } \\
\text { formation in relation to the auditing } \\
\text { disciplines, since the labor market demands } \\
\text { Organization (UNO), carried out in Geneva } \\
\text { (Switzerland), in February 1999. }\end{array}$ & $\begin{array}{l}\text { and this cannot be found with the recently- } \\
\text { formed professional. }\end{array}$ \\
\hline
\end{tabular}

To analyze if the auditing teaching has been met its hole in the student's qualification

Ricardino (2002) allowing them to have success in the labor market insertion as auditing professional. formation, therefore they had little or no practical experience in auditing, as well as the support material used as a basis during classes, was not updated, approaching the contents in a superficial way.

\begin{tabular}{l|l} 
& \\
\hline & $\begin{array}{l}\text { To analyze the audit, based on the audit } \\
\text { professional's perception, in order to } \\
\text { evaluate the discipline as specific or an } \\
\text { integral component in Accounting courses } \\
\text { other disciplines. }\end{array}$
\end{tabular}

\begin{tabular}{l|l|l} 
& \\
\hline
\end{tabular}

Teachers and auditors' differences of opinion on the content distribution of the content that is taught in the discipline, as well as the prerequisites demands and teacher's practical experiences.

To analyze the audit teaching main characteristics in the Accounting graduate courses from Goiania and Aparecida de Machado et al. (2014) Goiania higher education institutions to evaluate if that education meets the great audit firms' needs (Big Four) regarding the graduated professionals.

\begin{tabular}{l|l} 
& \\
\hline
\end{tabular}

To analyze the student's profile of the Accounting course from a public university regarding his interest in the auditor's career.

\begin{tabular}{l|l|} 
& regarding his interest in the auditor's career. \\
\hline &
\end{tabular}

To analyze the students and professional's audit teaching perception to evaluate the main conceptual and normative aspects related to the preparation for the labor market.
Lack of experience of some teacher's evidence in the audit area of some teachers, in accordance with the managers of the Big Four investigated, is of extreme importance in auditing teaching. Still, despite audit international standards showing as topics in the disciplines program contents, there are no direct quotations regarding auditor's technical and personal standards during class.

More than $60 \%$ of the students have demonstrated an interest in the auditor's career and any profile was found that was fully put off as for the audit teaching.

Approximately $75 \%$ of the subjects analyzed in the academy correspond to the market expectations. Still, due to the auditing discipline course load decrease, the deepening in certain necessary matters to the practice of auditing and to contextualize between theory and practice, become impossible for teachers restricting audit teaching in a general and superficial overview.

Source: Prepared based on Machado et al. (2014), Madeira (2001), Ricardino (2002), Silva (2008), Silva et al. (2016), Hoff et al. (2017). 


\section{Methodological Procedures}

In terms of the problem's approach, this study is classified as quantitative (Michel, 2015), since it aims to quantify students' opinion about audit teaching aspects of the labor market. Regarding the objectives, this research is descriptive (Gil, 2006), bearing in mind that describes the investigated population's characteristics and elucidates the students' perception of the asked questions. With respect to the technical procedures used, this study is classified as data collection or survey (Gil, 2006), since a questionnaire was applied to the UFRGS Accounting course pupils from groups of Auditing I and of Auditing and Applied Accounting Inspection, called Group 1 (G1) and the students from Inspection and Audit Specialization course (NECON/UFRGS) are the Group $2(\mathrm{G} 2)$. One can stress that the data analysis is descriptive-argumentative, knowing that it was seeking to capture respondents' characteristics through statistics methods (Colauto, \& Beuren, 2013).

The data collection was made through a structured questionnaire with amended open and closed questions from Rodrigues, Moreira, Firmino and Silva (2016) - the study approached the Accounting pupils' perception on the account's inspection teaching and the labor market -, as well as of theoretical input. The application was carried out in December 2017, in the groups of Auditing I and Auditing and Applied Accounts Inspection. Yet, in the group of Inspection and Auditing Specialization, the data were obtained through an online questionnaire, during January 2018. The sample composition is illustrated in Table 2.

Table 2

Composition of the Research Sample

\begin{tabular}{l|c|c}
\multicolumn{1}{c|}{ Group } & Students enrolled & Total of Respondents \\
\hline Audit I $\left(7^{\circ}\right.$ semester) & 60 & 39 \\
\hline Audit and Applied Accounts Inspection $\left(8^{\mathbf{0}}\right.$ semester) & 69 & 34 \\
\hline Total G1 & $\mathbf{1 2 9}$ & $\mathbf{7 3 ( 5 6 , 5 8 \% )}$ \\
\hline Inspection and Auditing Specialization Course & 26 & $15(57,69 \%)$ \\
\hline Total G2 & $\mathbf{2 6}$ & $\mathbf{1 5 ( 5 7 , 6 9 \% )}$ \\
\hline
\end{tabular}

Source: Created based on data from the sample research (2018).

According to Table 2, G1 was composed of 73 answered questionnaires $(56,58 \%)$ and G2 by $57,69 \%$ of the suitable pupils answering the sent questionnaire (15). Besides, due to the population of the study be formed by Accounting graduates (G2), who were seeking for the improvement of their knowledge, realizing the Inspection Auditing Specialization course, and for probable Accounting trainees (G1), some questions were different for these two groups. For the closed questions, the obtained data were tabulated and analyzed through its average percentages, standard deviation, and variance, highlighting the identified characteristics in each categorized group. And, the open questions consisted of the construction of a summary of all answers, presented in the form of text.

\section{Data Analysis}

In this section the respondents' profile, the students' perception of audit teaching in the Accounting course and in the Specialization, as well as the pupils' preparation for the labor market. 


\subsection{Respondents' Profile}

Table 3 shows the respondents' profile of both groups of the sample, as well as information about the course and the professional performance.

Table 3

Respondents' Profile

\begin{tabular}{|c|c|c|c|}
\hline Categories & Subcategories & $\begin{array}{c}\text { Group } 1 \\
(\%)\end{array}$ & $\begin{array}{c}\text { Group } 2 \\
(\%)\end{array}$ \\
\hline \multirow{7}{*}{ Age } & From 18 to 20 years old & 1,4 & - \\
\hline & From 21 to 25 years old & 49,3 & - \\
\hline & From 26 to 30 years old & 30,1 & 40,0 \\
\hline & From 31 to 35 years old & 8,2 & 20,0 \\
\hline & From 36 to 40 years old & 5,5 & 13,3 \\
\hline & From 41 to 60 years old & 4,1 & 20,0 \\
\hline & More than 60 years old & 1,4 & 6,7 \\
\hline \multirow{2}{*}{$\begin{array}{l}\text { Semester that is being effectively in the course (higher } \\
\text { number of disciplines) }\end{array}$} & Seventh semester & 53,4 & - \\
\hline & Eight semester & 46,6 & - \\
\hline \multirow{2}{*}{ Currently working? } & Yes & 91,8 & 86,7 \\
\hline & No & 8,2 & 13,3 \\
\hline \multirow{2}{*}{ Perform or has performed any auditing activity? } & Yes & 17,8 & 46,7 \\
\hline & No & 82,2 & 53,3 \\
\hline \multirow{2}{*}{ If "YES", intend to continue performing audit activities? } & Yes & 69,2 & 100,0 \\
\hline & No & 30,8 & - \\
\hline
\end{tabular}

Source: Created based on data from the sample research (2018).

In Table 3, regarding the age of the respondents, in Group 1 approximately $80 \%$ have between 21 to 30 years old and a little over 5\% it has more than 40 years old. Such result resembles the study of Silva et al. (2016), who also found the sample higher concentration between 22 to 30 years old and lesser grouping when related to the respondents with more than 40 years old. Differently of the Group 1, the age of the researched ones in Group 2, that has the post-graduation students, bunched between 26 and 35 years old, demonstrating more than $60 \%$ of the sample and, above 40 years old, it is possible to show almost $27 \%$ of the studied ones up. It is worth pointing out that, in Group 1, 53,4\% of the respondents are attending the seventh semester of UFRGS Accounting course and in Group 2 there is no such classification.

When asked if they were working, more than $90 \%$ of G1 and more than $86 \%$ of G2 are acting in the labor market, and of those, under $18 \%$ of G1 and $47 \%$ of G2 practiced or have practiced auditor's activities, the factor that demonstrates that the graduation pupils still detain little knowledge about auditing practical living, corroborating the results demonstrated in the study of Silva et al. (2016), where $70 \%$ of the sample that were inserted in the market, only $3 \%$ were in the area of auditing. Still, for those who informed that they were working with auditing, $70 \%$ of G1 were striving for continuing in the area, and in G2 100\% intend to continue on the audit branch, showing the coherence of this group as its members are attending a specialization in this field.

To complement the respondents' profile, specifically regarding the labor market and the professional performance, they were questioned about the claim of professional performance. The answers of the two groups are exposed in Figure 1. 


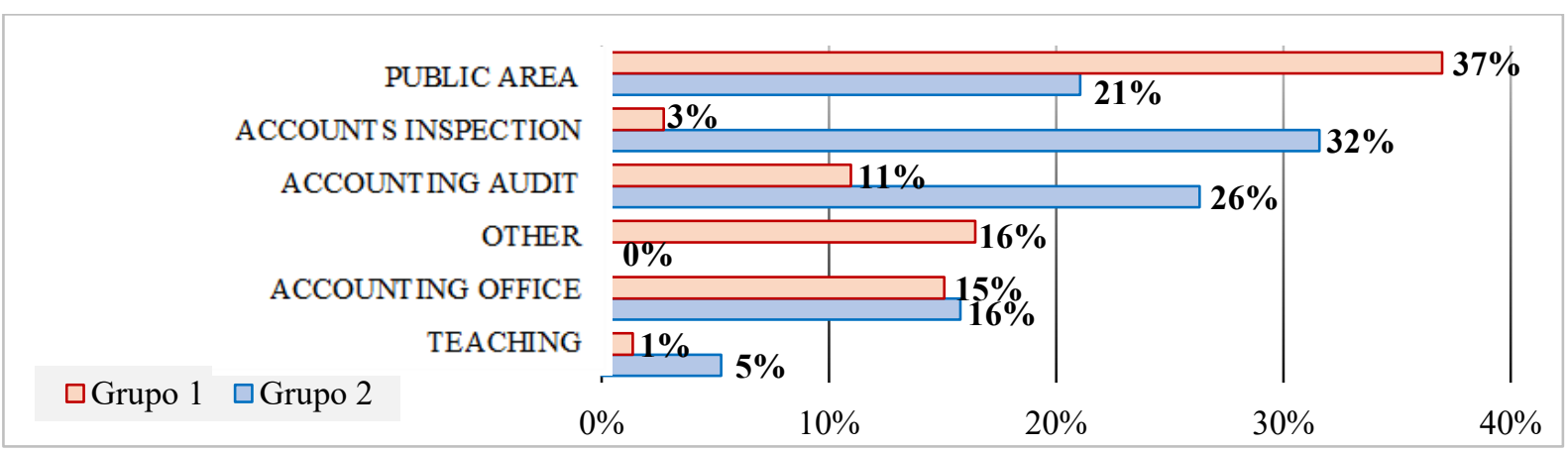

Figure 1 Professional performance pretension

Source: Created based on data from the sample research (2018).

Analyzing Figure 1, it is observed that the most professional pretension chosen by G1'a respondents is the "Public Area" (37\%), followed by "Other" category (16\%) and the option "Accounting Office/Accounting Entrepreneur" (15\%), and the choice "Accounting Audit" is in the fourth position with $11 \%$. In the alternative "Others" it was necessary to inform the intended area for the professional performance, the most cited were "Consultancy", "Agribusiness Accounting" and "Risk Analysis in the Bank Section" branches. In G2, the following ambitions stood out: "Accounting Expertise" (32\%), "Accounting Audit" (26\%), and "Public Area" (21\%). It calls attention to the respondents' will to act in the public section, meeting the results found by Rodrigues et al. (2016).

In the question regarding the respondents' professional claim, it was requested the investigated ones to relate at least three motivational factors that make them choose that professional area. Among the mostly cited there are the options related to the remuneration, stability, knowledge and professional growth, as well as in Silva et al.'s study (2016), which has as one of the most attractive factors in the auditor's career is the remuneration; knowledge acquisition and the experience, and the relevance of the profession.

When the participants were questioned about the interest continuing the studies after the Accounting course completion (G1), and after the Inspection and Auditing Specialization course completion (G2), the answers obtained are illustrated in Table 4.

\section{Table 4}

Interest in continuation of the studies after the conclusion of the course

\begin{tabular}{l|c|c}
\hline Options of Study & Group 1 (\%) & Group 2 (\%) \\
\hline (1) Specialization & 54,8 & 40,0 \\
\hline (2) Master & 6,9 & 20,0 \\
\hline (3) PhD & 1,4 & - \\
\hline I do not have interest & 17,8 & 26,7 \\
\hline Specialization and Masters & 6,9 & 13,3 \\
\hline Checked Options 1, 2, 3 simultaneously & 8,2 & - \\
\hline Checked Options 2, 3 simultaneously & 4,1 & - \\
\hline
\end{tabular}

Source: Created based on data from the sample research (2018).

Analyzing Table 4 it is noticed that more than the half of the respondents of the G1 have interest in continuing the studies, at least to attend a specialization $(54,8 \%)$, as well as others that also intend to attend the specialization as well as a master's degree and doctorate, or do not attend the specialization course and follow straightly to master's degree, and afterwards the doctorate. In $\mathrm{G} 2$, most of the respondents have an interest in continuing the studies $(73,3 \%)$, attending another specialization or a master's degree, or both of them. 
However, none of the respondents of this Group showed interest in attending doctorate, besides that both Groups have an elevated number of respondents that have no interest in continuing the studies, representing almost $18 \%$ of G1 and over $25 \%$ of G2.

Regarding the areas that aim to continue the studies, the most quoted are tax area, finances, and Controllership, and there are no answers related to the auditing. Such result demonstrates academic continued education student's lack of credibility as a way of inserting in the labor market or as an updating, it could be occasioned due to several students do not have the audit practice living, as shown in Hoff et al. (2017) study.

\subsection{Perception about Audit Teaching}

As for pedagogical practices adopted in the auditing class, Figure 2 brings that each respondent marked at least three options diverse from pedagogical practices used by the teachers in the audit disciplines.

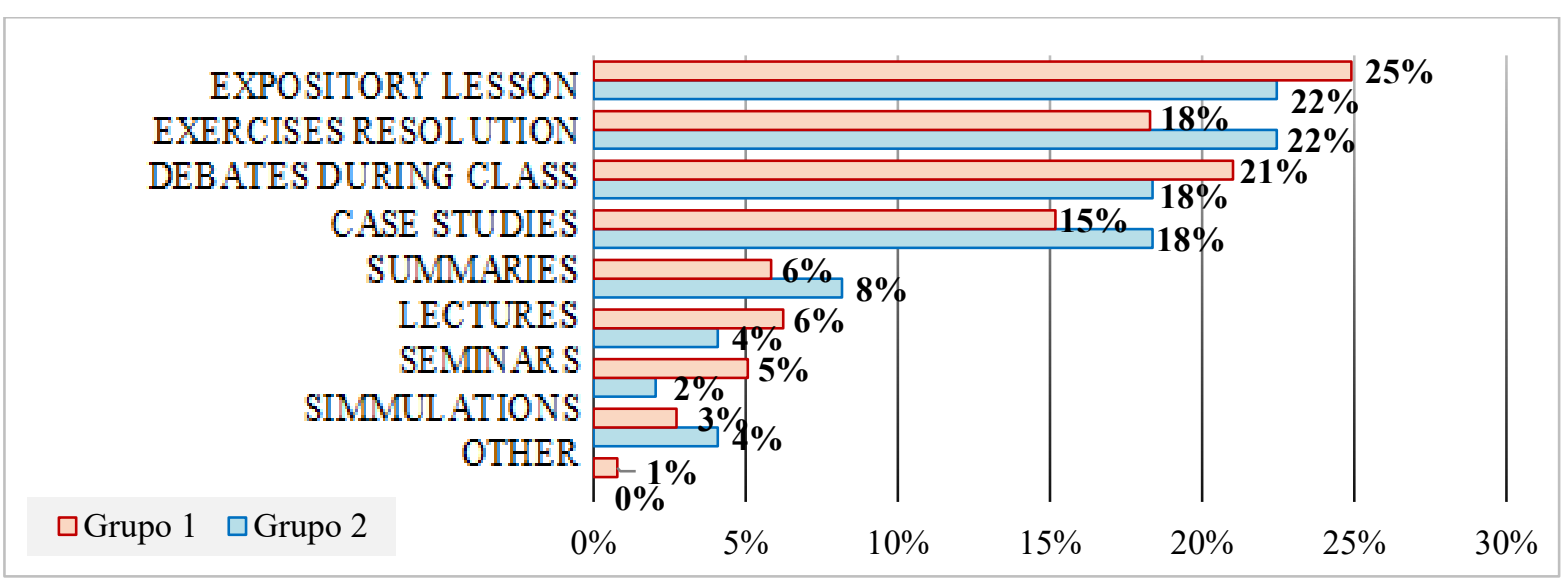

Figure 2 Pedagogical practices followed in Auditing

Source: Created based on data from the sample research (2018).

According to Figure 2, it can be identified that the pedagogical practices most adopted by the teachers in both Groups are "Expository Class", "Discussions in Class", "Exercises Resolutions", and "Case Studies". Regarding the relation to the teaching method "Case Study", which is among the most used by the Auditing teachers, it is quoted by Madeira (2001), as a form of development in the studies of the discipline, a teacher works in class with an organization's real situation to stimulate the student to develop the necessary abilities for the problem resolutions during work day by day. In the question, there was also the option "Other", so respondents would inform different pedagogical exercises adopted by the teachers and that was not in the available options. Among the answers are "Works in Group" and "Music."

In Silva and Bruni's (2017) study, methodologies, seminars, debates, problems discussions, discussion of cases, and works in groups are mainly used, and these are recognized by the literature as active pedagogical practices in class. However, the authors detach that the teachers should analyze, from the planning, so that those learning techniques do not become passive, where the student has the responsibility of exposing the content and there is no debates or subsequent questioning.

Concerning the level of importance of points that deserve a deeper approach in audit teaching, the interviewees needed to attribute for each investigated the option value in the 
scale of 1 to 5, being: 1 - Without Importance, 2 - Least Important, 3 - Without Opinion, 4 Important, and 5. Very Important. Group 1 and Group 2 results are demonstrated in Table 5.

\section{Table 5}

Level of importance in issues to a deeper approach in the Audit teaching

\begin{tabular}{l|c|c|c|c|c|c}
\hline \multirow{2}{*}{\multicolumn{1}{c}{ Level of Importance }} & \multicolumn{3}{c|}{ Group 1 } & \multicolumn{3}{c}{ Group 2 } \\
\cline { 2 - 7 } & Average & $\begin{array}{c}\text { Standard } \\
\text { Deviation }\end{array}$ & Variance & Average & $\begin{array}{c}\text { Standard } \\
\text { Deviation }\end{array}$ & Variance \\
\hline Accounting Brazilian Standards & 4,64 & 1,54 & 2,36 & 4,87 & 1,89 & 3,58 \\
\hline Practice on detecting frauds & 4,59 & 1,38 & 1,91 & 4,67 & 1,46 & 2,14 \\
\hline Audit Planning & 4,58 & 1,45 & 2,10 & 4,93 & 2,06 & 4,24 \\
\hline Execution of Audit works & 4,57 & 1,37 & 1,89 & 4,93 & 2,06 & 4,24 \\
\hline $\begin{array}{l}\text { Applicable Legislation to the Accounts } \\
\text { Auditing }\end{array}$ & 4,52 & 1,29 & 1,66 & 5,00 & 2,24 & 5,00 \\
\hline Civil Procedures Code & 3,56 & 0,75 & 0,56 & 3,80 & 1,00 & 1,01 \\
\hline Historical and Conceptual Aspects & 3,16 & 0,67 & 0,45 & 3,67 & 1,09 & 1,19 \\
\hline Source: Created
\end{tabular}

Source: Created based on data from the sample research (2018).

On the basis of the Table 5, the points in G1 that deserve a deeper approach in the audit teaching are the ones related to the "Brazilian Standards of Accountancy", with average of importance of 4,64 from the total of 5 scales, followed by the "Projection of the Auditing" with 4,59, and the "Practice in the detection of frauds" with 4,58. These data were founded and reveal the students' perception as for the apprenticeship needs that require more work from the teachers, in other words, they would like to receive more knowledge on these points, aiming a better qualification for the labor market. These results corroborate the finds of Machado et al. (2014), which emphasized the importance of the Professional Standards and Audit Technic.

In the face of the variance analysis, it is possible to affirm that the more uniform answers were related to "Civil Process Codes" and "Historical and Conceptual Aspects" and these also presented a lesser degree of dispersal, in relation to the average, since the standard deviations were inferior to $10 \%$. The most unequal were "Brazilian Standards of Accountancy" and "Projection of the Auditing", because they presented bigger variances standard deviations, in relation to the average regarding the average, which indicates the amplitude of answers spread through the levels of importance.

In addition, the fact that the "Brazilian Accounting Rules" have been pointed by G1 as the most skimpy in teaching meets Castañeda et al.'s (2007) founding. These discoveries consider that auditor competencies are not only linked to the pieces of evidences, but also to the procedures' accomplishment in order to guarantee that the accounting statements are being elaborated in accord with the international norms and other applicable legislation.

For G2, the points that deserve a deeper approach in audit teaching, according to Table 5 are "Applicable Legislation to Accounting Audit" that all the respondents considered as very important content for the future auditors' development. In the sequence, there are the topics "Audit Planning" and "Audit Execution" with an average of 4,93 in relation to the scale, evincing perception from the respondents, of great importance to each one of those points in the audit teaching. As in G1, the answers are shown more uniforms and with little dispersion in relation to the average, because the standard deviations were tiny, acted by the items "Codes of Civil Process" and "Historical and Conceptual Aspects".

The most unequal was "Audit Planning" and "Audit Execution" since they presented the largest variances and the standard deviations revealing width in the respondents' 
perception. When comparing the results of G1 and G2 it is observed that even with some working and having concluded the Accounting qualification, they understand that legislation is relevant in the audit performance and the teachers need to have a greater focus on class. In addition, regarding the relevance of Auditing in the academic qualification, Table 6 is presented.

\section{Table 6}

Audit relevance in the students' academic qualification

\begin{tabular}{l|c|c}
\hline Level of Relevance & Group 1 (\%) & Group 2 (\%) \\
\hline Highly relevant to qualify myself as a well-trained professional. & 49,3 & 33,3 \\
\hline Highly relevant, because I work / I intend to work in the auditing area. & 19,2 & 46,7 \\
\hline Little relevant, only to complement a general knowledge. & 27,4 & 20,0 \\
\hline Not relevant, because I will not perform in the auditing area. & 2,7 & - \\
\hline Not relevant, because I will not perform in the accounting area. & 1,4 & - \\
\hline
\end{tabular}

Source: Created based on data from the sample research (2018).

According to Table 6, for G1, almost $50 \%$ of the respondents mentioned auditing as "Highly Relevant to qualify myself as a well-qualified professional" and the option "is not relevant, because I will not act in the accounting area" was the lesser quoted with $1,4 \%$. In G2, the "Highly relevant, because I work/I intend to work in the auditing area", with $46,7 \%$ of the respondents were the preferred choice "Little relevant, just to complement general knowledge" the least chosen. Thus, as an auditor can work either in internal or external auditing, it is inferred that the interviewees only visualize the importance of a good qualification in Auditing not only to act as an independent auditor but also concerning the aid to the organizations' administration. They will possess knowledge and ability to verify the controls and processes that have been settled in the correct way or if they need review and improvements (Franco, \& Marra, 2000). With respect to the audit discipline's content as enough for the understanding of the matter, it is displayed in Table 7.

\section{Table 7}

Sufficient substance for the understanding of the Audit discipline

\begin{tabular}{l|c|c}
\hline Substance sufficiency for the understanding of the discipline & $\begin{array}{c}\text { Group 1 } \\
(\%)\end{array}$ & $\begin{array}{c}\text { Group } 2 \\
(\%)\end{array}$ \\
\hline Yes, I consider the course content fully satisfactory. & 9,6 & 20,0 \\
\hline Yes, but for a basic understanding of the discipline. & 64,4 & 33,3 \\
\hline I consider it insufficient and I would like to have more substance of this matter. & 12,3 & 46,7 \\
\hline I consider it insufficient, But I would not like to have more substance of this matter. & 5,5 & - \\
\hline I don't know / I prefer to not give opinion. & 6,9 & - \\
\hline NR (Not Responded). & 1,4 & - \\
\hline
\end{tabular}

Source: Created based on data from the sample research (2018).

According to Table 7 , for almost $65 \%$ of G1's respondents, the content learned in the auditing discipline will be enough only for the basic understanding of the subject. In G2, almost half $(46,7 \%)$ of the respondents understand that the content is insufficient and they would like to have more subjects about auditing. In this way, remains the reflection to the teachers to revise the teaching plans for these disciplines, regarding the content and the workload, as well as offering other auditing disciplines. Where they will provide conversations, courses and complementary capabilities aiming to combine theory and practice since the results founded in the analyzed Groups have indicated that the students do not feel prepared to work in the audit branch only with the content studied in the classroom. 
This vision of auditing teaching does not fully prepare the pupils, is also shared with Madeira (2001) and they corroborate the vision of Armitage (2008), which emphasizes that the constant changes in the auditing work development, not only in the practice but also in the teaching. Its education accounting process must be re-valued continuously, in order to address the necessities of a changeable society and prepare in the appropriate form the future professionals of the area for runs of success in the market.

\subsection{Audit Teaching and its Preparation for the Labor Market}

Through Table 8, student's perception is illustrated in terms of audit content implications as sufficient knowledge for the performance in the labor market.

\section{Table 8}

Sufficient substance for the performance of the function in the labor market

\begin{tabular}{l|c|c}
\hline Substance sufficiency for the performance in the labor market & Group 1 (\%) & Group 2 (\%) \\
\hline Yes, I believe it is more than enough for the labor market. & 2,7 & 6,7 \\
\hline Yes, I believe this is what is expected for the labor market. & 31,5 & 33,3 \\
\hline I consider insufficient and I am concerned about the Labor Market. & 37,0 & 46,7 \\
\hline I consider insufficient, but I am not concerned about the Labor Market. & 12,3 & 6,7 \\
\hline I don't know / I prefer to not give opinion. & 16,4 & 6,7 \\
\hline
\end{tabular}

Source: Created based on data from the sample research (2018).

In Table 8 , approximately $37 \%$ interviewed of G1 believe that auditing content is insufficient to fulfill the function and they are preoccupied with the labor market. Other $31,5 \%$ understand that this is expected by the labor market, whereas only $2,7 \%$ consider more than sufficient for the performance of this professional activity. For those who evaluate as sufficient, it can have relation with the constant profile in Table 3, where 17,8\% are already working with auditing, in other words, they know how this position in practice.

Answers from G2, composed by specialization pupils, who ended the Accounting course, has similar reading to G1 since $46,7 \%$ of the respondents find the auditing content insufficient in the course and they are worried about the labor market. 33,3\% believe that this is expected in the labor market and a little less than $7 \%$ of the respondents think that the content is more than sufficient for auditing performance in the labor market. This Group's result can also be divergent according to Table 3, that shows that $46,7 \%$ informed that they have already realized auditing activities.

The students were questioned about the motivational factors that bring you to study or not about auditing. The results as for the motivation are expressed in Table 9 and as for the lack of motivation, its results are in Table 10.

\section{Table 9}

Motivation for studying about Auditing

\begin{tabular}{|c|c|c|}
\hline What motivates/has motivated you to study about auditing & $\begin{array}{l}\text { Group } 1 \\
(\%)\end{array}$ & $\begin{array}{l}\text { Group } 2 \\
(\%)\end{array}$ \\
\hline $\begin{array}{l}\text { (1) To master the content about the account practice related to the audit legislations } \\
\text { and rules. }\end{array}$ & 19,2 & 46,7 \\
\hline (2) To know the indispensable for the profession's good performance. & 26,0 & 13,3 \\
\hline (3) To connect theory with the account practice, aimimg at the market demands. & 20,6 & 26,7 \\
\hline (4) To be approved in the subjects. & 19,2 & 13,3 \\
\hline (5) I do not have motivation to study about auditing. & 9,6 & - \\
\hline Options 2 and 3. & 2,7 & - \\
\hline Options 3 and 4. & 1,4 & - \\
\hline
\end{tabular}


Options 1,2 and 3.

Source: Created based on data from the sample research (2018).

Analyzing Table 9, the most pointed factor as motivation to study auditing, in G1, it was to "Know the indispensable for the good performance of the profession", with $26 \%$, followed by "To connect theory with accounting practice, seeking market demands", with approximately $21 \%$. Approximately $10 \%$ mentioned that they do not have the motivation to study about auditing, a factor that demonstrates that the pupils probably do not identify themselves with the area, but as they are in the graduation course, they need to be approved in the discipline since it is strongly required. In G2, almost half of the respondents have marked that the reason to study on auditing was "To dominate the content on the accounting practice in relation to the legislation and auditing norms", followed by the item "To relate theory to accounting practice, aiming market demands", what evidences the concern with the job market in this area. This way, for Castro et al. (2017) the students are enrolled in a specialization course due to the needs imposed by the market and its expectations of the auditor's work.

\section{Table 10}

Demotivation to study about auditing

\begin{tabular}{l|c|c}
\hline What demotivate/has demotivated you to study about auditing? & $\begin{array}{c}\text { Group 1 } \\
\text { (\%) }\end{array}$ & $\begin{array}{c}\text { Group 2 } \\
(\%)\end{array}$ \\
\hline I do not have reasons to demotivate me on studying about this matter. & 41,1 & 80,0 \\
\hline The legislation complexity and other rules demotivate me. & 26,0 & 6,7 \\
\hline I believe that there are more rentable areas to invest my time on studying. & 19,2 & - \\
\hline $\begin{array}{l}\text { The lack of a Support from the teacher or a expert professional in the área } \\
\text { demotivate. }\end{array}$ & - & 6,7 \\
\hline The way how Auditing is presented in the course demotivate. & 12,3 & 6,7 \\
\hline NR (Not Responded). & 1,4 & - \\
\hline
\end{tabular}

Source: Created based on data from the sample research (2018).

In relation to the factors that put the auditing study on, it is evinced Table 10 as respondents of both G1 and G2 in the majority signed that they do not have reasons for such. This result can be due to many from G1 and G2 are working or are acting in the area, according to Table 3. However, in G1 it was also chosen the option related to the complexity of the legislation and auditing standards, being one of the factors that put the auditing study of, bearing in mind its continuing mutations in the long run (Castañeda et al. 2007). Still, it is presented the opinion about the audit labor market in Table 11.

\section{Table 11}

Opinion about the audit labor market

\begin{tabular}{l|c|c}
\hline Opinion about the labor market for Accounts Auditing & Group 1 (\%) & Group 2 (\%) \\
\hline $\begin{array}{l}\text { I know the Accounts Auditing area and I feel I am prepared to work as na } \\
\text { auditor. }\end{array}$ & 12,3 & 53,3 \\
\hline I believe it would be interesting, but I know a little about the area. & 68,5 & 33,3 \\
\hline I do not have Interest and I know a little about the area. & 13,7 & 13,3 \\
\hline I do not know the area. & 5,5 & - \\
\hline
\end{tabular}

Source: Created based on data from the sample research (2018).

Observing Table 11, almost $70 \%$ of the respondents of G1 judged to be an interesting market, however, they consider they know little about the area. In G2, little more than the half of the respondents have about the field and they feel prepared to work as auditors, and about 
$33 \%$ consider to be interesting, but they know little about the area, corroborating Silva's (2008) research. Where although almost $60 \%$ of the sample demonstrated an interest in the auditing discipline, such interest is shown medium due to the lack of opportunity to put the teachings into practice as they are mostly just theoretical. Hoff et al. (2017) affirm that exists a growing concern of the teachers in the insertion of methodologies that make possible that practical knowledge of their students, this would allow the auditing concept application and theoretical outline in order to develop students' knowledge in the area.

\section{Final Considerations}

This study aimed to analyze UFRGS Accounting Students' perception regarding the teaching of the auditing discipline and his/her preparation for the insertion into the labor market, as well as the perception of NECON/UFRGS Inspection and Auditing Specialization course pupils. For that, a questionnaire with open and closed questions was elaborated, and applied in person to UFRGS Accounting course students and sent online for the pupils of the Inspection and Auditing Specialization course, called as Groups 1 (G1) and Groups 2 (G2), respectively.

It was verified that the majority of both groups are in the labor market, however, when asked if they have worked or are still working in auditing, most part of the two groups did not make it, confirming Madeira's (2001) vision, in which Accounting pupils have not been sufficiently prepared concerning the subject connected with auditing, in other words, after the graduation they feel unprepared to face the labor market. However, it showed up that, of the respondents that act or have acted in the audit area, almost $70 \%$ from Group 1 and $100 \%$ from Group 2 intend to keep on acting in the auditing labor market. Thus, after getting professional practice in the area the students feel enabled to keep on working in this field.

As for the pedagogical practices more used by the teachers, it was identified that in both Groups as "Expository Class"; "Discussions in Class"; "Exercise Resolutions"; and "|Case Studies". For Hoff et al. (2017), the auditors of the market see as ideal for the professionals' good development the combination of those pedagogical practices. Another important aspect was the points that deserve a deeper approach in the teaching of Audit, being in Group 1 the "Brazilian Accounting Norms", followed by "Auditing Planning", and "Practice in fraud detection." And in Group 2 the points "Applicable Legislation to Accounting Audit", followed by the points related to "Audit Planning" and "Auditing Execution" works.

It is highlighted that the students' perception in relation to the sufficiency of auditing discipline content for the acting of the function, because of $37 \%$ of Group 1 respondents and almost half of Group 2, they believe that the audit content is insufficient to carry out the function and they are worried about the job market. And, the factor that motivates more the students to study about Auditing was to know the indispensable for the good acting of the profession and to dominate the content on the accounting practice related to auditing norms and legislation.

The results indicate that the students, as well as in graduation level than in specialization they do not feel prepared to face the job market, even if the teachers use several pedagogical teaching practices, because the pupils feel that there are teaching "deficiencies" regarding the continuous changing legislation. That unpreparedness sensation can be originated from the expected knowledge that job market holds these professionals in function of their role as auditing the accounting statements. 
Thereby, it is evident the importance that Auditing gained in the market and the role that it undertakes. However, for the faithful execution of its purposes, due to the continuing changes in the applicable legislation, as the convergence of the Accounting to the international patterns, it is indispensable the Accounting alignment as a whole. It is also necessary to adapt the courses curricula, enhancing the audit teaching and to better prepare the students for the job market. Like this, Accounting graduation is shown as the student's way out into the job market, with the necessary updating to perform the accountant's profession, as well as the auditor.

This research contributes to the identification of the Accounting course students' learning difficulties, regarding the auditing discipline, allowing to propose improvement actions in the teaching and consequently in the accounting profession, affecting the accountant's formation as a whole. The study identified the students' motivations for the choice of auditing area, as well as it analyzed the ones that have chosen for this area, but also feel the need to be in a continuous study due to this field demands, mainly the external audit that has specific Brazilian Accounting Norms regulating their activities.

Finally, in order to hone and to diversify audit teaching, providing a further exploit of the knowledge of the students in the job market. It is recommended to integrate the pupils with the professional practice, through workshops held by auditors operating in the market, as well as seminars and classes that expose real situations and practical works that engage the students as participants in the auditing simulations, elucidating practical cases and the work methodology used. Among the limitations, difficulty can be found in obtaining a higher quantity of participating students in the study and the focus in only one higher education institution. In future studies, it is suggested to realize this research with other higher education institutions in the same area or on a national level, that will allow comparison and an understanding of other teaching practices adopted in the auditing classes.

\section{References}

Alberton, L., \& Beuren, I. M. (2003). A formação comportamental de Auditores Contábeis Independentes: um estudo multicaso. Revista Eletrônica de Ciência Administrativa, Campo Largo, 1(2), 1-24.

Almeida, M. C. (2012). Auditoria: um Curso Moderno e Completo. (8a ed.). São Paulo: Atlas.

Armitage, J. (2008). Changes in the importance of topics in auditing education: 2000-2005. Managerial Auditing Journal, [s.1.], 23(9), 935-959.

Armitage, J., \& Poyzer, J. K. (2010). Academicians' and practitioners' views on the importance of the topical content in the first auditing course. American Journal of Business Education, [s.1.], 3(1), 71-82.

Barreto, D., \& Graeff, F. (2011). Auditoria: teoria e exercícios comentados. (2a ed.). São Paulo: Método.

Camargo, R. C. C. P., Camargo, R. V. W., Dutra, M. H., \& Alberton, L. (2013). A percepção dos auditados em relação às competências comportamentais dos auditores Independentes: um estudo empírico na Região da Grande Florianópolis/SC. Revista de Contabilidade e Organizações, São Paulo, 7(18), 37-47. 
Castañeda, B. E. G., Carvalho, L. N. G., \& Lisboa, N. P. (2007). Comparação entre as Normas de Auditoria do Brasil e as Internacionais (IAASB). Revista Contemporânea de Contabilidade, Florianópolis, 1(7), 81-100.

Castro, R. L. C., Vasconcelos, J. P. B., \& Dantas, J. A. (2017). Impactos das Normas Internacionais de Auditoria nos Relatórios dos Auditores sobre as Demonstrações Financeiras dos Bancos Brasileiros. Revista Ambiente Contábil, Natal, 9(1), 1-20.

Chaffey, J., Van Peursem, K. A.; \& Low, M. (2011). Audit education for future professionals: perceptions of new zealand auditors. Accounting Education, 20(2), 153-185.

Colauto, R. D., \& Beuren, I. M. (2013). Coleta, Análise e Interpretação dos Dados. In Beuren, I. M. (Org.). Como Elaborar Trabalhos Monográficos em Contabilidade: teoria e prática. (3a ed.). São Paulo: Atlas, 117-144.

Franco, H., \& Marra, E. (2000). Auditoria Contábil. São Paulo: Atlas.

Gil, A. C. (2006). Como elaborar projetos de pesquisa. (4a ed.). São Paulo: Atlas.

Hoff, J., Alberton, L., \& Camargo, R. de C. C. P. (2017). A visão da academia e do mercado de trabalho sobre o ensino da auditoria. Revista de Educação e Pesquisa em Contabilidade, Brasília, 11(1), 52-68.

Humphrey, C. (2008). Auditing research: a review across the disciplinary divide. Accounting, Auditing \& Accountability Journal, [s.1.], 21(2), 170-203.

Machado, L., Machado, M. R. R., \& Guerra, F. M. (2014). Formação do auditor nas instituições de ensino superior e a capacitação profissional nas firmas de auditoria. Revista de Contabilidade da UFBA, Bahia, 8(1), 4-20.

Madeira, C. A. (2001). Avaliação do ensino de Auditoria nos cursos de graduação em Ciências Contábeis: uma pesquisa exploratória. Dissertação de Mestrado em Controladoria Contabilidade Estratégica, Faculdade de Ciências Econômicas de São Paulo, Fundação Escola de Comércio Álvares Penteado, São Paulo.

Michel, M. H. (2015). Metodologia e pesquisa científica em ciências sociais: um guia prático para acompanhamento da disciplina e elaboração de trabalhos monográficos. (3a ed.). São Paulo: Atlas.

Oliveira, L. M., \& Diniz F. A. (2001). Curso básico de auditoria. São Paulo: Atlas.

Ricardino F. A. A. (2002). Auditoria: ensino acadêmico X treinamento profissional. Tese de Doutorado em Controladoria e Contabilidade, Faculdade de Economia, Administração e Contabilidade, Universidade de São Paulo, São Paulo. 
Rodrigues, A. C., Moreira, F. S., Firmino, J. E., \& Silva, M. C. (2016). A percepção dos alunos do curso de Ciências Contábeis acerca do ensino e do mercado de trabalho em perícia contábil. Revista Capital Científico, Guarapuava, 14(2), 93-108.

Silva, A. P. (2008). A percepção dos profissionais de auditoria quanto ao ensino de auditoria contábil nos cursos de graduação em Ciências Contábeis do Brasil. Dissertação de Mestrado em Ciências Contábeis, Programa Multiinstitucional e Inter-Regional de Pós-graduação em Ciências Contábeis, Universidade de Brasília/ Universidade Federal da Paraíba/ Universidade Federal do Rio Grande do Norte, Brasília.

Silva, M. C., Martins, V. F., \& Rocha, V. A. (2016). A profissão de auditor: como está a motivação dos discentes de Ciências Contábeis para seguir esta carreira? Revista de Auditoria, Governança e Contabilidade, Minas Gerais, 4(17), 154-174.

Silva, U. B., \& Bruni, A. L. (2017). O Que me ensina a ensinar? Um estudo sobre fatores explicativos das Práticas Pedagógicas no Ensino de Contabilidade. Revista de Educação e Pesquisa em Contabilidade, Brasília, 11(2), 214-230. 